\title{
Hubungan Nilai Hematokrit Terhadap Jumlah Trombosit pada Penderita Demam Berdarah Dengue
}

\author{
Amrina Rasyada ${ }^{1}$, Ellyza Nasrul $^{2}$, Zulkarnain Edward $^{3}$
}

\begin{abstract}
Abstrak
Demam Berdarah Dengue (DBD) merupakan salah satu masalah kesehatan masyarakat yang utama di Indonesia.Pemeriksaan nilai hematokrit dan jumlah trombosit menjadi indikator diagnosis DBD. Nilai hematokrit akan meningkat (hemokonsentrasi) karena penurunan volume plasma darah, sedangkan jumlah trombosit akan menurun (trombositopenia) akibat supresi sum-sum tulang dan munculnya antibodi terhadap trombosit. Penelitian ini bertujuan untuk mengetahui hubungan nilai hematokrit terhadap jumlah trombosit pada penderita demam berdarah dengue. Telah dilakukan penelitian retrospektif terhadap 112 pasien DBD di RSUP DR. M. Djamil Padang periode Juli 2012Juni 2013. Data yang diambil dari Instalasi Rekam Medis adalah nilai hematokrit dan jumlah trombosit yang diperiksa dengan menggunakan alat otomatis Pentra-60. Data dianalisis menggunakan uji korelasi Spearman. Hasil dari penelitian ini didapatkan rata-rata jumlah trombosit saat masuk rumah sakit adalah $49.627 \pm 38.141$ sel/mm3, sedangkan rata-rata nilai hematokrit saat masuk rumah sakit adalah $45,1 \pm 6,1 \%$. Analisis data untuk mencari hubungan nilai hematokrit terhadap jumlah trombosit saat masuk rumah sakit, didapatkan nilai koefisien korelasi Spearman $(r)$ sebesar $-0,115$ dan nilai signifikasi $p>0,05$. Kesimpulan dari hasil penelitian ini adalah terdapat peningkatan nilai hematokrit dan penurunan jumlah trombosit.
\end{abstract}

Kata kunci: demam berdarah dengue, nilai hematokrit, jumlah trombosit

\begin{abstract}
Dengue Hemorrhagic Fever (DHF) is a major public health problem in Indonesia. Examination of hematocrit values and platelet counts as indicators of dengue diagnosis. Hematocrit value will increase (hemoconcentration) due to a decrease in volume of blood plasma, while the platelet count will decrease (thrombocytopenia) due to bone marrow suppression and the appearance of antibodies against platelets. The objective of this study was to determine the relationship of hematocrit value on platelet counts in patients with dengue hemorrhagic fever. A retrospective study of 112 patients of dengue in the RSUP Dr. M. Djamil Padang period July 2012-June 2013. Data was taken from the Installation of Medical Record is the value of hematocrit and platelet, then data were examined using automated tools Pentra-60. Then the data were analyzed using the Spearman correlation test. The results of this study found the average platelet count on admission was $49.627 \pm 38.141 \mathrm{cells} / \mathrm{mm}^{3}$, while the average hematocrit value on admission was $45,1 \pm 6,1 \%$. Data analysis was then performed to find the relationship of hematocrit value of the platelet count on admission, obtained Spearman correlation coefficient $(r)$ of $-0,115$ and a significance value of $p>0,05$. It can be concluded that there is an increase in hematocrit and decrease of platelet counts.
\end{abstract}

Keywords: dengue hemorrhagic fever, hematocrit value, platelet counts

Affiliasi penulis : 1. Fakultas Kedokteran Universitas Andalas Padang), 2. Bagian Patologi Klinik FK UNAND, 3. Bagian Biokimia FK UNAND

Korespondensi: Amrina Rasyada, email : rinaarasyada@yahoo.co.id, Telp: 085367027202

\section{PENDAHULUAN}

Demam Berdarah Dengue (DBD) merupakan salah satu masalah kesehatan masyarakat utama di Indonesia. Perjalanan penyakit ini sangat cepat dan sering menjadi fatal karena banyak pasien yang 
meninggal akibat penanganannya yang terlambat. ${ }^{1}$ Saat ini, 40\% populasi dunia tinggal di daerah yang memiliki risiko terinfeksi DBD. ${ }^{2}$ Asia menempati urutan pertama dalam jumlah penderita DBD setiap tahunnya. Sementara itu, sejak tahun 1968 hingga tahun 2009, WHO mencatat negara Indonesia sebagai negara dengan kasus DBD tertinggi di Asia Tenggara. Di Indonesia, terdapat 11 (33\%) provinsi termasuk dalam daerah risiko tinggi DBD (Al>55 kasus per 100.000 penduduk). Sumatera Barat termasuk di dalamnya, yaitu urutan ke-10 dengan 60 kasus per 100.000 penduduk. $^{3}$

Berdasarkan data dari Dinas Kesehatan Kota Padang tahun 2010, DBD merupakan penyebab kematian terbanyak di Rumah Sakit Kota Padang. Pada awal tahun 2010 jumlah kasus DBD sebanyak 1045 kasus, angka ini turun dibanding tahun 2009 sebanyak 1586 kasus dan tahun 2008 sebanyak 1219 kasus. ${ }^{4}$

Pengenalan penyakit DBD saat masuk rumah sakit dapat menentukan prognosis baik atau buruk pada pasien. Pemeriksaan laboratorium yang dapat menunjang diagnosis DBD yaitu pemeriksaan nilai hematokrit dan jumlah trombosit. ${ }^{5}$

Patofisiologi utama pada DBD yaitu peningkatan permeabilitas vaskular dan hemostasis yang abnormal.Permeabilitas vaskular yang meningkat mengakibatkan kebocoran plasma, hipovolemi dan syok. Trombositopenia dapat menimbulkan gangguan hemostasis, menifestasi perdarahan seperti petekie, ekimosis, perdarahan gusi, epistaksis, hematemesis dan melena. ${ }^{6}$

Nilai hematokrit adalah konsentrasi (dinyatakan dalam persen) eritrosit dalam $100 \mathrm{~mL}$ darah lengkap. Nilai hematokrit akan meningkat (hemokonsentrasi) karena peningkatan kadar sel darah atau penurunan volume plasma darah, misalnya pada kasus DBD. Sebaliknya nilai hematokrit akan menurun (hemodilusi) karena penurunan seluler darah atau peningkatan kadar plasma darah, seperti pada anemia. $^{7}$ Trombosit merupakan sel darah yang berfungsi dalam hemostasis. Sel ini tidak memiliki nukleus dan dihasilkan oleh megakariosit dalam sumsum tulang. ${ }^{8}$ Pada pasien DBD terjadi trombositopenia akibat munculnya antibodi terhadap trombosit karena kompleks antigen-antibodi yang terbentuk. ${ }^{9}$

Berdasarkan penelitian Pusparini pada tahun 2004, nilai hematokrit dan jumlah trombosit saat masuk rumah sakit dapat dijadikan acuan dalam menentukan penderita sebagai dengue primer atau sekunder. $^{10}$

Parameter laboratorium dalam menegakkan diagnosis DBD adalah peningkatan nilai hematokrit serta trombositopenia. ${ }^{10}$ Berdasarkan data ini, perlu dilakukan penelitian tentang hubungan nilai hematokrit terhadap jumlah trombosit pada penderita Demam Berdarah Dengue di RSUP Dr. M. Djamil Padang. Tujuan penelitian ini adalah untuk mengetahui hubungan nilai hematokrit terhadap jumlah trombosit pada penderita demam berdarah dengue.

\section{METODE}

Jenis Penelitian ini adalah analitik retrospektif, populasi penelitian adalah seluruh rekam medik pasien rawat inap saat pertama kali masuk, dengan diagnosis Demam Berdarah Dengue (DBD) di Bagian Penyakit Dalam Rumah Sakit Umum Pusat Dr. M. Djamil Padang bulan Juli 2012-Juni 2013. Subjek berjumlah 112 orang yang diambil dengan metode total sampling. Kriteria inklusi adalah catatan rekam medik pasien DBD dewasa yang dilengkapi dengan identitas, keadaan umum pasien, hasil pemeriksaan laboratorium (nilai hematokrit dan jumlah trombosit). Kriteria eksklusi adalah pasien DBD yang memiliki riwayat penyakit kelainan darah, seperti AIHA dan ITP. Variabel bebas dalam penelitian ini adalah infeksi virus dengue, sedangkan variabel terikat adalah nilai hematokrit dan jumlah trombosit. Pengolahan data adalah pemeriksaan kelengkapan dan kejelasan data, pemberian kode pada setiap data variabel, memasukkan data dalam program SPSS (Statistical Program for Social Science), serta pemeriksaan kembali untuk memastikan bahwa data tersebut telah bersih dari kesalahan. Analisis data terdiri dari analisis univariat dan bivariat. Pada analisis bivariat dicari hubungan antara dua variabel dengan menggunakan rumus Spearman. 
HASIL

Tabel 1. Karakteristik Subjek Penelitian

\begin{tabular}{lccc}
\hline Karakteristik & $\mathbf{n}$ & mean \pm SD & $\boldsymbol{p}$ \\
& $(\%)$ & & \\
\hline Jenis Kelamin & 70 & & - \\
- Laki - laki & $(62,5)$ & - & \\
- Perempuan & 42 & & \\
& $(37,5)$ & & \\
& & & \\
Umur (tahun) & 45 & $25,1 \pm 11,4$ & \\
$-<20$ & $(40,2)$ & & \\
$-20-40$ & 53 & & \\
$->40$ & $(47,3)$ & & \\
& 14 & & \\
\hline
\end{tabular}

Ket: $n=$ frekuensi, $p=$ nilai signifikasi

Tabel 1 memperlihatkan sebagian besar subjek adalah laki-laki. Lebih dari separuh responden termasuk kelompok usia produktif.

Tabel 2. Distribusi Nilai Hematokrit Penderita DBD Saat Masuk Rumah Sakit

\begin{tabular}{lc}
\hline \multicolumn{1}{c}{$\begin{array}{c}\text { Nilai Hematokrit } \\
(\%)\end{array}$} & $\begin{array}{c}\mathbf{n} \\
(\%)\end{array}$ \\
\hline $\begin{array}{l}\text { Laki-laki } \\
-<40\end{array}$ & $5(4,5)$ \\
$-40-48$ & $27(24,1)$ \\
$->48$ & $38(33,9)$ \\
Perempuan & $5(4,5)$ \\
$-<37$ & $21(18,7)$ \\
$-37-43$ & $16(14,3)$ \\
$->43$ & $\mathbf{1 1 2 ( 1 0 0 \% )}$ \\
\hline \multicolumn{2}{c}{ Total }
\end{tabular}

Ket: $\mathrm{n}=$ frekuensi

Tabel 2 menggambarkan bahwa sebagian besar sampel memiliki nilai hematokrit di atas normal.

Tabel 3. Distribusi Jumlah Trombosit Penderita DBD Saat Masuk Rumah Sakit

\begin{tabular}{cc}
\hline $\begin{array}{c}\text { Jumlah Trombosit } \\
\left(\mathbf{s e l} / \mathbf{m m}^{\mathbf{3}}\right)\end{array}$ & $\begin{array}{c}\mathbf{n} \\
\mathbf{( \% )}\end{array}$ \\
\hline$<150.000$ & $112(100)$ \\
$150.000-400.000$ & 0 \\
$>400.000$ & 0 \\
\hline Total & $\mathbf{1 1 2 ( \mathbf { 1 0 0 } \% )}$ \\
\hline Ket: $\mathrm{n}=$ frekuensi &
\end{tabular}

Dari tabel 3 dapat diketahui bahwa semua sampel memiliki jumlah trombosit di bawah normal.
Tabel 4. Hubungan Nilai Hematokrit terhadap JumlahTrombosit pada Penderita Demam Berdarah Dengue

\begin{tabular}{ccc}
\hline Variabel & r & $\boldsymbol{P}$ \\
\hline Nilai HematokritPenderita & & \\
DBD & & \\
Saat Masuk RS & $-0,115$ & 0,226 \\
Jumlah Trombosit \\
Penderita DBD \\
Saat Masuk RS
\end{tabular}

Dari tabel 4 dapat dilihat bahwa hasil uji statistik didapatkan korelasi negatif dan $p>0,05$ yang berarti tidak bermakna.

\section{PEMBAHASAN}

Hasil penelitian mendapatkan penderita dengan usia terendah 10 tahun dan usia tertinggi 59 tahun dengan rata-rata usia penderita adalah 25,1 tahun. Usia terbanyak penderita DBD adalah usia 19 tahun. Selain itu, juga didapatkan frekuensi umur pasien DBD terbanyak adalah kelompok umur 20-40 tahun, dan frekuensi terendah adalah pada kelompok umur $>40$ tahun.

Hasil penelitian ini didukung oleh pernyataan dari Carribean Epidemiology Centrepada tahun 2000, yang menyatakan bahwa epidemiologi penderita DBD terbanyak adalah pada anak-anak dan dewasa muda. $^{12}$

Usia adalah salah satu faktor yang mempengaruhi kepekaan terhadap infeksi virus dengue. Penelitian di Kuba pada tahun 1981 menunjukkan bahwa usia mempunyai peranan yang penting untuk timbulnya gejala klinis berupa kebocoran plasma. ${ }^{12}$

Berdasarkan karakteristik jenis kelamin, didapatkan bahwa jenis kelamin laki-laki lebih banyak daripada perempuan dengan perbandingan 1,6: 1 . Hal tersebut serupa dengan penelitian lainnya yang memperlihatkan bahwa penderita laki-laki lebih banyak dibandingkan dengan perempuan seperti yang dilaporkan oleh Pusparini pada tahun 2004 bahwa di Rumah Sakit Atmajaya Jakarta jumlah kasus laki-laki lebih banyak daripada perempuan dengan perbandingan $1,2: 1 .^{10}$ Penelitian oleh Runtunuwu 
pada tahun 2007 memperlihatkan perbandingan jenis kelamin penderita DBD yang tidak berbeda antara lakilaki dan wanita dengan perbandingan $1,1: 1 .^{14}$

\section{Nilai Hematokrit Penderita DBD Saat Masuk Rumah Sakit}

Dari hasil penelitian, 48,2\% penderita DBD yang mengalami hemokonsentrasi dan $9 \%$ penderita mengalami hemodilusi., sedangkan, yang mempunyai nilai hematokrit normal sebanyak 42,8\%. Nilai hematokrit terendah saat masuk RS adalah $30 \%$ dan tertinggi sebesar 59\%. Rata-rata nilai hematokrit saat masuk RS pada penelitian ini adalah $45,1 \%$.

Menurut $\mathrm{WHO}$, parameter laboratorium dalam menegakkan diagnosis DBD adalah peningkatan nilai hematokrit serta trombositopenia. Sementara itu, penelitian ini menunjukkan bahwa tidak semua penderita mengalami hemokonsentrasi. Penelitian oleh Taufik dkk. pada tahun 2007 menyatakan bahwa hanya $16 \%$ penderita DBD yang mengalami peningkatan nilai hematokrit. ${ }^{15}$

Pada penelitian ini banyak pasien DBD yang memiliki nilai hematokrit normal bahkan rendah dan didiagnosis DBD. Parameter kebocoran plasma sebagai diagnosis DBD menurut WHO tidak hanya peningkatan nilai hematokrit saja, namun juga penurunan nilai hematokrit $>20 \%$ setelah mendapat terapi cairan juga menjadi indikator diagnosis. Kelemahan penelitian ini adalah tidak lengkapnya data rekam medis tentang pengobatan sebelum masuk rumah sakit.

Sebuah penelitian di India oleh Gomber pada tahun 2001 tentang parameter diagnosis DBD, mengatakan bahwa nilai hematokrit dapat meningkatkan spesifisitas sebesar $36.3 \%$ dalam diagnosis DBD namun menurunkan sensitifitas. ${ }^{16}$

Berdasarkan saran penelitian dari Pratiwi pada tahun 2011, pemisahan pasien laki-laki dan perempuan berdasarkan kadar hematokrit rujukan normal yang berbeda sebaiknya dilakukan. Berdasarkan jenis kelamin, terdapat perbedaan nilai normal hematokrit. Pada penelitian ini, nilai tertinggi untuk perempuan adalah $55 \%$, sedangkan nilai terendah hematokrit adalah 34\%. Untuk laki-laki, nilai tertinggi adalah 59\%, sedangkan nilai terendah hematokrit adalah $31,7 \%$. Rata-rata nilai hematokrit untuk laki-laki adalah 46,9\%, sedangkan untuk perempuan sebesar $42,1 \%$. Hasil analisis dengan uji Spearman didapatkan nilai $p=0,477$ yang berarti tidak terdapat korelasi yang bermakna antara nilai hematokrit laki-laki dan perempuan.

\section{Jumlah Trombosit Penderita DBD Saat Masuk Rumah Sakit}

Berdasarkan hasil penelitian, secara keseluruhan jumlah trombosit di bawah normal (trombositopenia) sebanyak 100\%. Jumlah trombosit $<100.000 \mathrm{sel} / \mathrm{mm}^{3}$ adalah sebesar $86,6 \%$. Jumlah trombosit terendah saat masuk rumah sakit adalah $10.000 \mathrm{sel} / \mathrm{mm}^{3}$ dan tertinggi sebesar 149.000 $\mathrm{sel} / \mathrm{mm}^{3}$. Rata-rata jumlah trombosit saat masuk rumah sakit pada penelitian ini adalah $49.627 \mathrm{sel} / \mathrm{mm}^{3}$. Jurnah dkk pada tahun 2011 juga mengatakan dalam penelitiannya bahwa sebanyak $71,40 \%$ penderita DBD memiliki jumlah trombosit $<100.000$ $\mathrm{sel} / \mathrm{mm}^{17}$

Berdasarkan penelitian Kelton dkk pada tahun 2011 bahwa jenis kelamin berhubungan dengan perbedaan sensitifitas dalam hal agregasi trombosit antara laki-laki dan perempuan. Selanjutnya disimpulkan bahwa trombosit laki-laki lebih sensitif dalam agregasi daripada trombosit perempuan. ${ }^{18}$

Pada penelitian ini, rata-rata jumlah trombosit untuk laki-laki adalah $53.874,6 \mathrm{sel} / \mathrm{mm}^{3}$, sedangkan untuk perempuan sebesar $42.547,6 \mathrm{sel} / \mathrm{mm}^{3}$. Hasil analisis dengan uji Spearman didapatkan nilai $p=0,937$ yang berarti tidak terdapat korelasi yang bermakna antara jumlah trombosit laki-laki dan perempuan.

\section{Hubungan Nilai Hematokrit terhadap Jumlah Trombosit pada Penderita DBD}

Dari hasil uji korelasi Spearman, didapatkan korelasi negatif dan nilai signifikansi $p>0,05$, berarti semakin besar nilai suatu variable maka nilai variable lainnya akan semakin kecil. Denganbegitu dapat disimpulkan bahwa semakin naik nilai hematokrit maka jumlah trombosit akan semakin menurun. Hal ini sesuai berdasarkan penelitian yang dilakukan oleh $J$ Am Coll Cardiol pada tahun 2002 menunjukkan bahwa terdapat korelasi negatif antara nilai hematokrit terhadap jumlah trombosit. ${ }^{19}$ Pada penelitian ini, didapatkan nilai signifikansi $p>0,05$ yang menunjukkan 
bahwa tidak terdapat korelasi bermakna diantara kedua variabel, sehingga dapat disimpulkan bahwa tidak terdapat hubungan antara nilai hematokrit dengan jumlah trombosit saat masuk rumah sakit pada pasien DBD.

\section{KESIMPULAN}

Dari hasil penelitian ini, dapat disimpulkan bahwa semakin besar nilai hematokrit maka jumlah trombosit akan semakin menurun.

\section{DAFTAR PUSTAKA}

1. Widoyono. Penyakit tropis: epidemiologi, penularan, pencegahan \& pemberantasannya Edisi ke-2. Jakarta: Erlangga; 2011.

2. Centers for Disease Control and Prevention. How to reduce your risk of dengue infection?. [serial online] 2012 (diunduh 23 April 2013). Tersedia dari:URL: HYPERLINK www.cdc.gov/dengue/.

3. Kementerian Kesehatan RI. DBD di Indonesia tahun 1968-2009. Buletin Jendela Epidemiologi Demam Berdarah Dengue. 2010; 2:1-14.

4. Dinas Kesehatan Kota Padang. Profil kesehatan kota Padang tahun 2010. Padang: DKK.; 2011.

5. World Health Organisation. Dengue hemorrhagic fever. [serial online] 2009 (diunduh 23 April 2013).

Tersedia dari: URL: HYPERLINK http:// www.who.int.

6. Shepherd SM. Dengue fever [serial online] 2007 (diunduh 27 April 2013). Tersedia dari:URL: HYPERLINK

http://.www.emedicine.medscape.com.

7. Sutedjo AY. Mengenal penyakit melalui hasil pemeriksaan laboratorium. Yogyakarta: Amara Books; 2007.

8. Sloane E. Anatomi dan Fisiologi. Jakarta: ECG; 2004

9. Suhendro N, Chen L, Khie. Demam berdarah dengue. Dalam: Aru S, editor (penyunting). Buku Ajar IImu Penyakit Dalam Jilid III. Edisi ke-5. Jakarta: Interna Publishing; 2009.

10. Pusparini. Kadar hematokrit dan trombosit sebagai indikator diagnosis infeksi dengue primer dan sekunder. Jurnal Kedokteran Trisakti. 2004;23(2): 51-6.

11. Soedarmono SP. Masalah demam berdarah dengue di Indonesia. Dalam: Hadinegoro, Satari $\mathrm{HI}$, editor (penyunting). Demam Berdarah Dengue. Edisi ke-1. Jakarta: Balai Penerbit FKUI; 2005.

12. Carribean Epidemiology Centre. Clinical and laboratory guidelines for dengue fever and dengue haemorrhagic fever/dengue shock syndrome for health care providers. Journal of Pan American Health Organization. 2000; 1-10.

13. Sutaryo. Perkembangan patogenesis demam berdarah dengue. Dalam: Hadinegoro, Satari HI, editor (penyunting). Demam Berdarah Dengue. Edisi ke-1. Jakarta: Balai Penerbit FKUI; 2004.

14. Runtunuwu AL. Studi perbandingan pengobatan demam berdarah dengue derajat III dan derajat IV. Jurnal Sari Pediatri. 2007; 8(3):42-7.

15. Taufik A, Didit Y, Farid W. Peranan kadar hematokrit, jumlah trombosit dan serologi lgGIgM antiDHF dalam memprediksi terjadinya syok pada pasien demam berdarah dengue (DBD). Jurnal Penyakit Dalam. 2007; 8(2):105-11.

16. Gomber S, Ramachandran VG, Kumar S, Agarwal KN, Gupta P, Dewan DK. Hematological observations as diagnostic markers in dengue hemorrhagic fever-a reappraisal. Indian Pediatrics Journal. 2001; 38: 477-81.

17. Jurnah $M$, Arif $D$, Bahar $M$, Burhanuddin. Uji hematologi pasien terduga demam berdarah dengue indikasi rawat inap. Indonesian Journal of Clinical Pathology and Medical Laboratory. 2011; 17(3): 139-42.

18. Kelton JG,Powers P, Julian J, Boland V, Carter CJ, Gent M. Sex related differences in platelet aggregation: influence of the hematocrit. Blood Journal of American Society Hematology. 2011; 56(1): 38-41

19. J Am Coll Cardiol. Relationship between platelet count and hematocrit. JACC Journals. 2002; 39(6):1072-17 